much safer place to live in than the woods of temperate regions. Crises are rare; day after day passes in a peaceful, almost monotonous routine". Is it not possible that a similar pattern of life history mortality, high when very young, low thereafter, and a lack of seasonal changes, have enabled the evolution of high diversity both in the tropical forest and in the deep sea? If this is so, the critical specialisations would presumably be in minimising the early mortality in various ways, and small brood sizes may be a necessary part of these specialisations, by making detection by predators more difficult ${ }^{4}$. There would then be much less pressure for niche specialisation among the adults.

\section{MARK WILLIAMSON}

Department of Biology,

University of York.

York, $U K$

1. Wolff, T. Nuture 267, 780-785 (1977).

Sanders. H. L. Browkhaten Simp. Biol. 22, 71-81 (1969)

Dayton. P. K. \& Hessler, R. R. Deep-Sea Res. 19, 199208 (1972)

4. Snow. D. W. The Whe of Adapration. Bird Studies in the American Tropics (Collins, London, 1976).

\section{Contemporaneity of late Cretaceous extinctions}

THE dramatic extinctions at the end of the Cretaceous, both on land and in the sea, have long provoked speculation, but there is little direct evidence. Their existence is why the Cainozoic Era is distinguished from the Mesozoic, and in practice they are used in stratigraphy to make the Cretaceous-Palaeocene boundary. If the extinctions occurred at different times in different places, this practice would have to be revised.

Butler et al. ${ }^{1}$ presented magnetostratigraphic evidence that dinosaur extinction in northern New Mexico occurred slightly later than the marine extinctions in central Italy. They seem to generalise this difference to all marine and terrestrial rock sequences, but this may be incorrect.

On the basis of extensive evidence of diverse kinds from Montana, we have been able to reconstruct ecologically the process of terrestrial extinctions there (refs 2-4 and unpublished). The time scale was ecologically very long but geologically very short $\left(10^{4}-10^{5} \mathrm{yr}\right)$, just as in marine sequences $^{5,6}$. The process, which affected marsupials almost as severely as dinosaurs but left the freshwater community entirely unaffected, was a protracted ecological succession which seems to have operated mainly by diffuse competition with placental and multituberculate mammals. This invading mammalian community ${ }^{7,8}$ soon expanded worldwide to give rise to most of our familiar Cainozoic mammals.

We have predicted ${ }^{2,3}$ that terrestrial extinctions farther south occurred later than those in Montana, but we were able to find ${ }^{2}$ only two flimsy data relevant to this prediction. Both were from South America and both supported the prediction. The extinctions in Montana were probably not the earliest, as dinosaurs occurred at least to about $75^{\circ} \mathrm{N}$ palaeolatitude ${ }^{2,9}$ and we expect that dinosaurs disappeared here a little before they did near $50^{\circ} \mathrm{N}$ in Montana.

It would be a remarkable coincidence if the great marine and terrestrial extinctions did not have causal elements in common. We believe that these extinctions were in part synchronous but that the terrestrial extinctions moved south as the rapidly evolving placental mammals expanded out from their ancestral temperate community. Dinosaurs may well have survived into the Eocene in India ${ }^{2}$, which was an island during the critical interval.

Leigh Van Valen

Department of Biology,

University of Chicago,

Chicago, Illinois 60637

\section{Robert E. Sloan}

Department of Geology and Geophysics, University of Minnesota,

Minneapolis, Minnesota 55455

1. Butler, R. F., Lindsay, E. H., Jacobs, L. L. \& Johnson, N. M. Nature 267, 318-323(1977)

Van Valen, L. \& Sloan, R. E. Evol. Theory 2, 37-64 (1977)

3. Van Valen, L. \& Sloan, R. E. Proc. 24th Int. Geol. Cong. 7, 214 (1972)

4. Sloan, R. E. Science 146, 430 (1964); in Athlon (ed. Churcher, C. S.) 134-154 (Royal Ontario Museum, Toronto, 1976)

5. Percival, S. F., Jr \& Fischer, A. G. Evol. Theory 2 , -305 (1977).

6. Worsley, T. R. thesis Univ. Illinois.

Sloan, R. E. \& Van Valen, L. Science 148, 220-227

(1965).
Van Valen, L. \& Sloan, R. E. Science 150, 743-745; 1796(1965)

9. Rouse, G. E. \& Srivastava, S. K. Canadian J. Earth Sci.9,1163-1179(1972).

\section{Do fatty acids inhibit gibberellin-induced amylolysis?}

BULLER et al. ${ }^{1}$ reported that fatty acids inhibit gibberellin-induced amylolysis in barley endosperm. Their experiments as described do not show if the effect is on induction of amylase by gibberellin, on amylase activity, or on resistance of starch to amylase attack, although they discuss results as "the exceptional efficacy of pentanoic $\left(\mathrm{C}_{5}\right)$ and nonanoic $\left(C_{9}\right)$ acids in overcoming the effect of GA ...".

Mitchell and Zillmann ${ }^{2}$ showed that fatty acids increased flour and starch pasting ability, and some years ago I measured similar effects. In the Amylograph $^{3}$, with the naturally occurring enzymes inactivated $^{3}$, a wheat flour had maximum paste viscosity 1,205 Brabender Units (BU). Fatty acid additions (500 mg each to the mixture of $60 \mathrm{~g}$ flour and $440 \mathrm{ml}$ water) gave the follow- ing increases of maximum viscosity, confirming Mitchell and Zillmann's observations: $\mathrm{C}_{6}, 45 \mathrm{BU} ; \mathrm{C}_{7}, 85 \mathrm{BU}$; $\mathrm{C}_{8}, 160 \mathrm{BU} ; \mathrm{C}_{8}, 125 \mathrm{BU} ; \mathrm{C}_{10}, 10 \mathrm{BU}$ and $\mathrm{C}_{11}, 5 \mathrm{BU}$.

If the flour enzymes (including amylases) were not inactivated, then $C_{8}$ fatty acid had remarkably greater effect. Adding $500 \mathrm{mg}(58 \mu \mathrm{mol}$ per $\mathrm{g}$ flour, or $7.9 \mathrm{mM}$ ) increased viscosity from $495 \mathrm{BU}$ to $975 \mathrm{BU}$. This effect for very low amylase activity suggests that fatty acid altered starch properties and made it more resistant to enzymatic breakdown. Commercial glyceryl monostearate (GMS) has a similar effect but GMS plus $C_{8}$ acid was no more effective than one component, nor did glyceryl monocaprylate strengthen starch more markedly than equimolar amounts of $\mathrm{C}_{8}$ acid or GMS.

I suggest that fatty acids about $C_{8}$ can make starch more resistant to amylase degradation. Thus the effect demonstrated by Buller et al. could be of fatty acid making starch more resistant to amylolysis rather than an effect associated with gibberellin.

\section{Peter Meredith}

\author{
Wheat Research Institute, \\ DSIR, Christchurch, \\ New Zealand
}

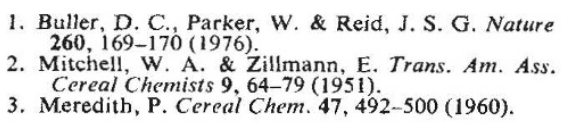

BULLER AND REID REPLY-We have reported that saturated fatty acids of chain length around $\mathrm{C}_{9}$ are potent inhibitors of gibberellin-triggered amylolysis in embryo-free barley halfgrains $^{t}$. We are aware that the efficacy of these acids "in overcoming the effect of GA" might be due either to their interfering with some aspect of the production, activation or secretion of amylolytic enzymes or to their inhibition of the amylolytic enzymes themselves. We are now investigating the biochemical mechanism(s) of fatty acid action.

In experiments carefully controlled to eliminate fatty acid effects on amylase activity in our assay systems we have observed that the fatty acids of chain lengths $\mathrm{C}_{7}, \mathrm{C}_{8}$ and $\mathrm{C}_{9}$ at $5 \times 10^{-4} \mathrm{M}$ completely inhibit the release of amylase activity from gibberellintreated barley aleurone layers. This suggests that the fatty acids can interfere, directly or indirectly, with amylase 'induction' or release.

Yet fatty acids can also inhibit the activity of amylolytic enzymes. Nonanoate $\left(\mathrm{C}_{9}\right)$ at $10^{-3} \mathrm{M}$ reduces by about $60 \%$ (relative to a citrate control) the 